Caskey, C. D., Norris, L. C. \& Heuser, G. F. (1944). Poult. Sci. 23, 516.

Couch, J. R. \& Cravens, W. W. (1947). Unpublished data from Wisconsin Agricultural Experimental Station. Quoted by Taylor, L. W, (1949).

Craft, W. A., M'Elroy, C. H. \& Penquite, R. (I926). Poult. Sci. 5, 187.

Cravens, W. W., McGibbon, W. H. \& Sebesta, E. E. (1944). Anat. Rec. 90, 55.

Cruickshank, E. M. (1940-1). Nutr. Abstr. Rev. 10, 645.

Dann, W. J. \& Handler, P. (194r). F. biol. Chem. 140, 935.

Davis, H. J., Norris, L. C. \& Heuser, G. F. (1938). Poult. Sci. 17, 81.

Ellis, N. R., Miller, D., Titus, H. W. \& Byerly, T. C. (1933). F. Nutr. 6, 243.

Engel, R. W., Phillips, P. H. \& Halpin, J. G. (1940). Poult. Sci. r9, 135.

Ferguson, T. M., Alexander, W. F. \& Couch, J. R. (1956). Poult. Sci. 35, 1 r41.

Ferguson, T. M. \& Couch, J. R. (1954). F. Nutr. 54, 36r.

Ferguson, T. M., Rigdon, R. H. \& Couch, J. R. (I955). Arch. Path. 60, 393.

Ferguson, T. M., Rigdon, R. H. \& Couch, J. R. (1957). Endocrinology, 60, 13.

Garcia, T. P. \& Paredes, J. R. (1957). Rev. Patronato Biol. anim. 3, 78.

Gillis, M. B., Heuser, G. F. \& Norris, L. C. (1942). Poult. Sci. 21, 470.

Gillis, M. B., Heuser, G. F. \& Norris, L. C. (1947). Poult. Sci. 26, 540.

Grau, C. R. \& Taylor, L. W. (1948). Poult. Sci. 27, 665.

Hill, D. C., McConachie, J. D., Gartley, K. M. \& Branion, H. D. (r950). Poult. Sci. 29, 744.

Insko, W. M. Jr. \& Lyons, M. (1936). Bull. Ky agric. Exp. Sta. no. 363 .

Jensen, L. S. \& McGinnis, J. (1957). Poult. Sci. 36, 312.

Johnson, D. Jr. \& Fisher, H. (1956a). F. Nutr. 60, 26r .

Johnson, D. Jr. \& Fisher, H. (1956b). F. Nutr. 60, 275.

Johnson, D. Jr. \& Fisher, H. (I958). Brit. F. Nutr. 12, 276.

Kurnick, A. A., Svacha, R. L., Reid, B. L. \& Couch, J. R. (1956). Poult. Sci. 35, 658.

Landauer, W. (1951). Bull. Storrs agric. Exp. Sta. no. 262.

Lepkovsky, S., Taylor, L. W., Jukes, T. H. \& Almquist, H. J. (1938). Hilgardia, rr, 559.

Lillie, R. J., Olsen, M. W. \& Bird, H. R. (1949). Proc. Soc. exp. Biol., N.Y., 72, 598.

Lorentz, F. W., Abbott, V. K., Asmundson, V. S., Adler, H. E., Kratzer, F. H., Ogasawara, F. Y. \& Carson, J. D. (1959). Circ. Calif. agric. Exp. Sta. no. 472.

Lowe, J. S., Morton, R. A., Cunningham, N. F. \& Vernon, J. (1957). Biochem. 7. 67, 215,

Lyons, M. \& Insko, W. M. Jr. (1937). Bull. Ky agric. Exp. Sta. no. 37 I.

Olcese, O., Couch, J. R., Quisenberry, J. H. \& Pearson, P. B. (1950). F. Nutr. 41, 423.

O'Rourke, W. F., Bird, H. R., Phillips, P. H. \& Cravens, W. W. (1954). Poult. Sci. 33, I I 7.

Rogler, J. C., Parker, H. E., Andrews, F. N. \& Carrick, C. W. (r959). Poult. Sci. 38, 398.

Romanoff, A. L. \& Bauernfeind, J. C. (1942). Anat. Rec. 82, I I.

Scott, M. L. (1957). Proc. 12th Distillers Feed Research Conference, Cincinnati, p. 6r.

Singsen, E. P., Matterson, L. D., Bunnell, R. H., Kozeff, A. \& Jungherr, E. L. (I954). World's Poult. Congr. x. Edinburgh, p. 25 I.

Snell, E. E. \& Quarles, E. (194r). F. Nutr. 22, 483 .

Taylor, L. W. (1947). Poult. Sci. 26, 372.

Taylor, L. W. (1949). Fertility and Hatchability of Chicken and Turkey Eggs. London: Chapman \& Hall Ltd.

Titus, H. W., Byerly, T. C., Ellis, N. R. \& Nestler, R. B. (1937). Poult. Sci. 16, I 18.

Temperton, H. \& Dudley, F. J. (1946). Harper Adams Util. Poult. Y. (N.S.4.), 31, 6r.

Temperton, H. \& Dudley, F. J. (1948). Harper Adams Utill. Poult. F. (N.S.4.), 33, 1.

Wilgus, H. S., Gassner, F. X., Patton, A. R. \& Harshfield, G. S. (I948). Poult. Sci. 27, 686.

\title{
Influence of nutrition on reproduction in laboratory rodents
}

By Annie M. Brown, Margaret J. Cook, W. Lane-Petter, G. Porter and A. A. Tuffery, Laboratory Animals Centre, M.R.C. Laboratories, Woodmansterne Road, Carshalton, Surrey

It is almost a platitude that diet is closely related to reproduction. Even with good nutrition and management $20-25 \%$ of both farm and laboratory livestock matings 
are infertile. Further losses from conception onwards are to a greater or lesser extent attributable to feeding. It may be rewarding to review some of the feeding methods that are hopefully considered to give normal reproduction and growth in the smaller laboratory animals before discussing any effects of particular nutrients.

Some methods widely used in the production of farm livestock have been successfully applied in the production of laboratory animals. Parkinson (1956), discussing the feeding and breeding of rabbits, describes 'steaming up' as applied to these animals. The does are mated 3 days after the previous litter is weaned and for the first I4 days after mating they are fed on a diet designed to keep them fine. Experienced breeders are well aware of the depressing effect of a fattening diet on the ability of animals to conceive and bear young successfully. When pregnancy is confirmed, the does are transferred to a much richer diet, given ad lib., for the remainder of the gestation period and throughout lactation. Sandford, King-Wilson \& Muir (1957) confirmed that rabbits required additional energy and protein during the last half of pregnancy, which should rise to twice maintenance requirements at parturition and three times maintenance during the first weeks of lactation. 'They also found that the diet requirement of heavily worked stud bucks was $15-20 \%$ above maintenance. In order to support full growth of the progeny their protein requirement was about twice that for maintenance, declining to maintenance level as the animals matured.

Reid (1958) found that a diet containing 20\% protein was adequate for normal growth of guinea-pigs, and has drawn attention to litter size and birth weight and the variation of litter size with strain. The inherent factors affecting the mothering ability of the sow and the additional nutrition needed during its reproductive life appear to have been overlooked. Although guinea-pigs can survive with little maternal help, animals retarded during the nursing period never attain the fast normal growth noted in the progeny of a good lactating sow.

An important decision to make in animal husbandry is the age at which to wean the offspring of a particular species. One of us (G. Porter), while breeding rats for a specific purpose at the Rowett Research Institute, experimented on the optimal weaning time for these animals. Each of a series of rat litters was reduced to six males. Two of them were weaned at $\mathrm{I} 7$ days old, two at 20 days old and two at 25 days old. On the $25^{\text {th }}$ day the two remaining with the mother were the heaviest, yet on the $35^{\text {th }}$ day the two weaned on the $17^{\text {th }}$ day were considerably heavier than the other four. It appeared that the young remaining longest with the mother laid down fat which they immediately lost when transferred to solid food.

Fresh drinking water must be made available at all times and to all species. Some species, for example the hamster, drink very little, but water consumption varies considerably with the physiological condition of the animal. The water consumption of a dairy herd is far higher than that of store cattle. Bruce (I950a), using rats, drew attention to rapid rise in water consumption during lactation and confirmed the need for increased food.

Russell ( 1948 ) found that most dietary deficiencies caused anorexia. The observed effects of such deficiencies on the oestrous cycles, reproduction and lactation may be 19 (1) 4 
primary, or they may be secondary to reduced food intake. Such findings can be checked by paired-feeding experiments, in which the sick animal controls the food consumed by the healthy one. We suggest that additional control by a normal animal fed ad lib. is essential to avoid misinterpretation of the results of paired feeding. Critical examination of certain work of this kind leaves much to be desired.

If food consumption is controlled either by impaired appetite or by restraint, normal reproduction and lactation cannot be expected. Ball, Barnes \& Visscher (1947) reported that the pregnancy rate in female mice was reduced by $70 \%$ when calorie intake was restricted to one-third of that of a control group fed without stint. Carr, King \& Visscher (1949) reported that oestrous cycles ceased when calorie intake was restricted by one-half.

All experimental methods in nutrition work need meticulous control. Weeks (I957) stated that 'recent discoveries have resulted in feeding practices which have accelerated the growth rate as measured by weight gain. At the same time, some animals with a promising growth performance fail to come into profitable production or have a short reproductive life'. She found that it was necessary to know what structural changes and chemical variations in the tissues and body fluid were taking place. Development of the bone, for example, could not be measured by an increase in weight. Over 20 years ago Orr \& Richards (1934) showed that the bones of vitamin A-deficient rats continued to increase in length, and Cuthbertson (1957) found that in certain circumstances when animals were given the high-calorie diet necessary for reproduction their vitamin requirements were greatly increased.

A study of the Carworth Farms Quarterly letters from October 1957 to October 1958, which have been concerned with reviewing the work on the nutrition of the laboratory rat, leaves the impression that the most suitable diet for optimal growth and reproduction is still unknown. Certain principles can be stated. For example, digestible protein must be high, probably of the order of $20 \%$, and the digestible elements of the diet must not be diluted unduly by indigestible material, usually shown in the analysis as 'fibre'.

Sherman, Campbell \& Ragan (1949) found that a ration containing $20 \%$ protein produced larger, faster-growing and more fertile rats than one containing $16 \%$. An interesting corroboration of this work was made by De Meillon \& Paterson (I958), who found that from two groups of fifty pairs of mice fed on diets containing 20.2 and $12.8 \%$ protein, fifty-seven and three litters respectively had been produced at 9 weeks after mating. The number of mice per litter was $7 \cdot 45$ and 4 respectively, and the number weaned 7.05 and 3 . Goettsch $(1948,1949)$ made a study of growth, reproduction and lactation in rats on a diet of polished wheat, kidney bean and casein. She found that $16.7 \%$ was the minimum protein requirement, and that the maintenance requirement of $300 \mathrm{~g}$ female rats was approximately half that necessary for growth and reproduction.

Another dietary requirement discussed in the Carworth review is that for fat. Evidently a larger proportion of fat (particularly that containing linoleic, linolenic and arachidonic acids) than is usually present in so-called adequate diets should be used, probably as much as $20 \%$. Natural ingredients of good quality contribute 
ample amounts of carbohydrate, vitamins and trace elements. Rats require all vitamins but $\mathrm{C}$ and $\mathrm{K}$, and their needs are greater for adequate reproduction than for maintenance. That an excess of one vitamin may lead to a deficiency in another, and that vitamins $A$ and $E$ are destroyed by rancid animal fats, are facts that should be borne in mind when compounding all diets for laboratory animals. Calcium, phosphorus, magnesium, manganese, potassium, iron and copper are all necessary in greater concentration for pregnancy and lactation than for maintenance diets.

The actual amounts of all dietary ingredients--protein, fat, carbohydrate, vitamins and trace elements - would therefore seem to depend on the intensity of reproduction required from the particular species being studied. Animals mated as monogamous pairs for their reproductive lives in order to take advantage of postpartum oestrus are subjected to greater stress than those that are separated during the birth and rearing of the litter and not remated until after weaning. This intensive breeding could be a stringent test of a good diet.

Palatability has at least a secondary effect on reproduction, for many animals would rather starve than eat an unpalatable diet. Several workers have found that rats will not readily eat a diet containing a high percentage of raw potato starch. In contrast, workers at the East African Virus Research Institute have reported that this same ingredient, when added to an ostensibly normal diet fed to Arvicanthus abyssinicus, an African rodent, suppressed cannibalism. In fully controlled experiments, Tribe \& Gordon (1953) found that rats allowed to choose between a palatable diet deficient in vitamins of the $\mathrm{B}$ complex, an unpalatable diet producing refection, and a palatable and completely adequate diet, all chose the palatable and complete diet. Paterson (1957) reports that guinea-pigs often leave untouched the white hearts of cabbage and savoys. We have observed that mice often waste enormous quantities of diet which is pulled through the wire baskets and not eaten.

In modern feeding of laboratory animals, palatability has seldom been considered worthy of note. C. Smith (private communication), in the production of rats, mice, golden and Chinese hamsters, has a separate diet sheet for each species and a daily feeding chart which varies over a period of 6-7 days. This method of feeding produces good results. Here at least no contribution is made to the common belief that a cube of sorts can be fed to laboratory animals irrespective of species, strain or appetence.

Parkes (1945-6) wrote that cubes and pelleted diets in wire hoppers had been a revolution in laboratory animal feeding. Did the pioneers of cube feeding, however, have the right approach? Thomson ( $193^{6}$ ) agreed that a diet varying from day to day gives good results under proper management but thought that a simple mixture of concentrates, properly balanced with vitamins and minerals and made into cube form, would give as good results, eliminating labour and saving time. Bruce \& Parkes (1949) described a cubed diet, no. 4r, as completely adequate to sustain rapid growth and intensive reproduction in rats and mice, but this cube has since been modified twice (Bruce, I950b; Bruce \& Parkes, I956).

Howie (I95I) described a diet, known as diet 86 , which has $5 \%$ dried-grass meal and a protein content of $20 \%$. Feeding of fresh grass and clover to the rat colony at the Rowett Research Institute had been practised for many years. Shano (1957) 
made a study of the composition of the food found in the stomachs of certain Muridae trapped in their natural habitat. He found that green plant food was dominant in nearly all the voles. Animal food was found in all species, invertebrate remains were found in nearly half the domestic mice. Few workers have actually made a study of the fundamental nutritional requirements of the animal as an animal rather than as a useful biological reagent.

Short \& Gammage (1959), describing a new pelleted diet, $\mathrm{SG}_{1}$, for rabbits and guinea-pigs, draw attention to the calculated protein content of diets i 8 (Bruce $\&$ Parkes, I945-6) and SGI as 16.5 and $14.7 \%$ respectively. Actual analysis showed that in the batches tested the protein content was 24.7 and $22.3 \%$ respectively. Both diets contain a high percentage of grass meal the protein of which may vary from $\mathrm{I}_{3}$ to $33 \%$, depending on the condition of the crop when harvested. Standardization of compounded diets is therefore dependent on two important factors, strict adherence to formulas and standardization of ingredients. Millers may control the former, but the latter is beyond their control and is dependent on normal farming hazards.

Purified diets containing the necessary amino acids, vitamins and minerals are highly desirable, but from the practical viewpoint of animal husbandry a good mixture of legumes, cereals and animal protein does a better job of maintaining a colony in full health and supports reproduction and lactation better than a theoretically balanced synthetic or semi-synthetic diet. Economy must be considered, but true economy is the production of the largest number of viable and healthy young in the shortest time.

\section{Conclusion}

Actual food consumption (irrespective of cost) is of minor importance in comparison with intelligent colony management. Maintenance and stress make very different demands on nutrition.

The chief stress in this sense is reproduction, which in so many laboratory-animal colonies is being forced to a level found neither in nature nor, until a few years ago, in laboratories. Diets to which we have tended to become too complacently accustomed do not always stand up to the rigours of modern breeding methods. A new diet that would consistently support intensive breeding in common laboratory rodents, that had a high acceptability to the animal, and that was taken in adequate amounts and not wasted, would be cheap at twice the price now being paid for currently used diets.

\section{REFERENCES}

Ball, Z. B., Barnes, R. H. \& Visscher, M. B. (1947). Amer. F. Physiol. I50, 5 I I.

Bruce, H. M. (1950a). Tech. Note Lab. Anim. Bur. no. 9.

Bruce, H. M. (1950b). F. Hyg., Camb., 48, I71.

Bruce, H. M. \& Parkes, A. S. (1945-6). F. Hyg., Camb., 44, 501.

Bruce, H. M. \& Parkes, A. S. (1949). J. Hyg., Camb., 47, 202.

Bruce, H. M. \& Parkes, A. S. (1956). F. Anim. Tech. Ass. 7, 54.

Carr, C. J., King, J. T. \& Visscher, M. B. (1949). Fed. Proc. 8, 22.

Cuthbertson, W. F. J. (r957). Coll. Pap. Lab. Anim. Bur. 5, 27. 
Goettsch, M. (1948). Arch. Biochem. 19, 349.

Goettsch, M. (1949). Arch. Biochem. 21, 289.

Howie, J. W. (1951). F. Anim. Tech. Ass. 2,6.

De Meillon, B. \& Paterson, S. (1958). S. Afr. med. F. 32, 1086.

Orr, J. B. \& Richards, M. B. (1934). Biochem. F. 28, 1259.

Parkes, A. S. (1945-6). 7. Hyg., Camb., 44, 491.

Parkinson, G. B. (1956). Consol. Bull. Lab. Anim. Bur. 1, 65.

Paterson, J. S. (1957). UFAW Handb., and ed. p. 203.

Reid, M. E. (1958). The Guinea Pig in Research. Washington, D.C.: Human Factors Research Bureau Inc.

Russell, F. C. (r948). Tech. Commun. Bur. Anim. Nutr., Aberd., no. I6.

Sandford, J. C., King-Wilson, W. \& Muir, R. O. (1957). UFAW Handb., and ed. p. 4II.

Shano, I. I. (r957). Zool. Z. 36, r084-ro92, (Predagog. Inst., Vorosilovgrad).

Sherman, H. C., Campbell, H. L. \& Ragan, M. S. (1949). F. Nutr. 37, 3 I7.

Short, D. J. \& Gammage, L. (I959). F. Anim. Tech. Ass. 9, 62.

Thomson, W. (1936). F. Hyg., Camb., 36, 24.

Tribe, D. E. \& Gordon, J. G. (1953). Brit. F. Nutr. 7, 202.

Weeks, G. G. (1957). Coll. Pap. Lab. Anim. Bur. 5, 21. 